\title{
Alexander Dovzhenko's Cinematic Visions
}

\author{
By George O. Liber
}

Spring 2000 Issue of KINEMA

\section{DEATH, BIRTH ORDER AND ALEXANDER DOVZHENKO'S CINEMATIC VISIONS}

"What man shall live and not see death, or save himself from the power of the

grave?" -- Psalms 89: 48

ALEXANDER Dovzhenko (1894-1956), one of the pioneers of Soviet filmmaking in the 1920s, created a cinematic universe with three types of death. His villains died "grotesquely," but his heroes experienced "beautiful deaths, without suffering."(1) The filmmaker considered only one type of death an absolute evil: the "senseless death", a category which included "the victims of war." (2) But for Dovzhenko, the loss of life in his films never became the final conclusion. As exemplified by the grandfather's death scene in Earth, dying constituted an integral part of the great chain of life. ${ }^{(3)}$

Dovzhenko created these interpretations specifically for the screen. His treatment of death did not express his true reaction to the end of life, an event he experienced frequently at close quarters. Most importantly, his experiences with death stimulated his creativity and appeared in revised form in his films.

Dovzhenko was born on August 29, 1894 ([Old Style]; September 10, 1894 [New Style]) to Petro Semenovych Dovzhenko and Odarka Ermolaivna Dovzhenko in Viunyshche, a district in the small town of Sosnytsia in the Chernihiv Province of Ukraine. ${ }^{(4)}$ The future filmmaker was born to a family of Ukrainian peasants, Cossacks who in the eighteenth century migrated to Sosnytsia from the neighbouring province of Poltava. Alexander became the seventh of fourteen children. ${ }^{(5)}$ But due to the multiple losses in his family, he became the oldest child by the time he turned eleven.

Death was a constant in the Dovzhenko family and in Alexander's environment. Ivan, Serhii, Vasyl, and Lavrin, his older brothers, passed away during a scarlet fever epidemic in 1895. Avram Petrovych (born in 1885), his oldest sibling, expired from typhus at the age of twenty as he worked as a stevedore in Rostov. ${ }^{(6)}$ His younger sister Anna breathed her last breath while giving birth. His other younger brothers and sisters, Gregory, Mykola, Kylina, Pasha, and Motria, departed during their childhood years. Alexander's youngest sibling, Andrii (born in 1910), died when he was sixteen. ${ }^{(7)}$ Of Petro and Odarka's fourteen children, only Alexander and Polina, his younger sister, survived into middle age.

The Dovzhenkos could not come to terms with the deaths in their family. Every new death reminded them of the previous one, and of the ones before that. Each member of the family had his or her own way of grieving. However different their reactions, they all belonged to the same emotional ecological system.

Senseless deaths like these often strengthen religious feelings, which attempts to provide a coherent interpretation of the irrational, the unacceptable, and the painful occurrences in life. By linking life, death, and the afterlife, religion provides solace and gives hope. In religious matters, the Dovzhenko family divided along gender lines. The men remained skeptics. Although Petro Semenovych prayed and crossed himself at meals, he was not very religious. He went to church occasionally, never fasted, and did not have a high opinion of the church or its servants. He considered priests to be "deceivers". ${ }^{(8)}$

In contrast, Odarka Ermolaivna increased her faith in God with every death. In the course of her life twelve of her fourteen children died; four in one day. These deaths sapped her emotionally and physically. Her hair turned gray before her thirtieth birthday and she cried often. ${ }^{(9)}$ Her children's deaths disabled her for long periods of time. She could not do the "woman's work" assigned by custom and tradition around the house. But her faith remained. In order to prevent the loss of her favourite child, Alexander, she often prayed: "O God, leave me Sashko; protect him from bad people. Give him strength. Give him happiness, so that people will love him as I love him."(10)

In addition to the deaths in his immediate family, Dovzhenko saw other people die. One memoirist recounted how Alexander reacted to the last moments of a neighbour's son, Petro Kopyl. While riding a horse, Petro 
dropped a pail he held. His horse panicked, bolted, and reared, throwing off the boy. Petro fell, but his foot became caught in a stirrup, causing the horse to drag him along the ground. By the time the horse stopped, Petro died. Drained of colour and shaking violently Alexander stood over the young boy's silent body. "How he then cried and cried!", one neighbour remembered. "Neither Petro's father or mother cried as much as Alexander did. After this accident Alexander Petrovych was sad and isolated himself from company ... for the entire summer." (11)

Although he did not serve in the tsarist army during the First World War and did not see first-hand the slaughter of his compatriots, he did see the war-wounded and war-crippled who flooded into Zhytomyr, where he taught from 1914 through the summer of 1917. ${ }^{(12)}$ Also, as a journalist with the front-line troops during the Second World War, he raced across the killing fields with the Soviet armies as they recaptured territories from the Germans. In the course of the war, in January 1943, his father died in German-occupied Kiev. He lay unburied for six days, until Alexander's mother "sold the remains of her clothes, made him a coffin, and then, old and alone, took him to the graveyard." (13) Such a horrid death disgusted Alexander, who loved his father very much. He must have felt that his father's death and delayed un-ceremonial burial to be undignified. His father's senseless death emphasized Alexander's own helplessness and vulnerability during the war.

Not only did Alexander see death, he himself almost died during the Civil War. After Pilsudski's Polish troops surrounded Zhytomyr in the spring of 1920, Alexander and a colleague left the city for Kiev, one hundred kilometres away. Polish soldiers captured them while they walked along the road. Since they did not have the proper documents, the Polish commander sentenced them to death. According to memoirists, Dovzhenko accepted his fate; his friend broke down. Just as the Poles were about to shoot them, a Soviet patrol arrived and after an exchange of gunfire rescued Alexander and his colleague. ${ }^{(14)}$

How did these deaths and Dovzhenko's near-death experience influence the future filmmaker? Although he admitted that the "questions of life and death affected my imagination when I was still a child so strongly that they left an imprint on all my work", he did not explain how. ${ }^{(15)}$ Did Dovzhenko grieve? If so, how? Did he feel guilty for being alive when his brothers and sisters died? For having been well when his siblings were ill? For past disagreements with his brothers and sisters? Did he feel jealous of his parents' grief over the deceased siblings? ${ }^{(16)}$ We do not know.

In his autobiographies, he did not describe or analyze how he reacted. The death of twelve of his brothers and sisters may have unleashed feelings of shock, pain, grief, loss, anger, guilt, and loneliness. We do not know which of these emotional ingredients he experienced, if at all, or in what proportion. Only in his films and only indirectly can we see how he reacted to all sad events.

Although he did not provide details, these deaths certainly contributed to his constant examination of the world and of his place in it. He admitted that he was "a dreamy little boy, inclined toward contemplation. My dreams and imagination were so strong that at times I lived on two levels - the real and the imaginary which struggled with each other and yet seemed reconcilable." ${ }^{(17)}$ He stopped being Sashko, Odarka's and Petro's child, and created Alexander, the hero of his most important script. Dovzhenko's examination of the world undoubtedly led to an awareness of a discrepancy between the "world that is and the world that 'should' be."(18)

He confronted the harsh realities of his childhood, youth, and adolescence by nurturing an active fantasy life. But his reaction to the passing away of his brothers and sisters produced more than just illusions. It left a significant imprint on his personal qualities and on his creativity.

Dovzhenko was born a middle child, but functionally became the oldest in 1905. As the oldest, he became the heir apparent and his family's most responsible child, obedient and pleasing to his parents. In obeying them, he began to take on the obligations and characteristics of the first-born child, which - according to Frank Sulloway - are different from those of later-bourns.

Sulloway's recent monograph, Born to Rebel: Birth Order, Family Dynamics, and Creative Lives, describes how individuals develop differing roles within the family. According to the author,

Siblings compete with one another in an effort to secure physical, emotional, and intellectual 


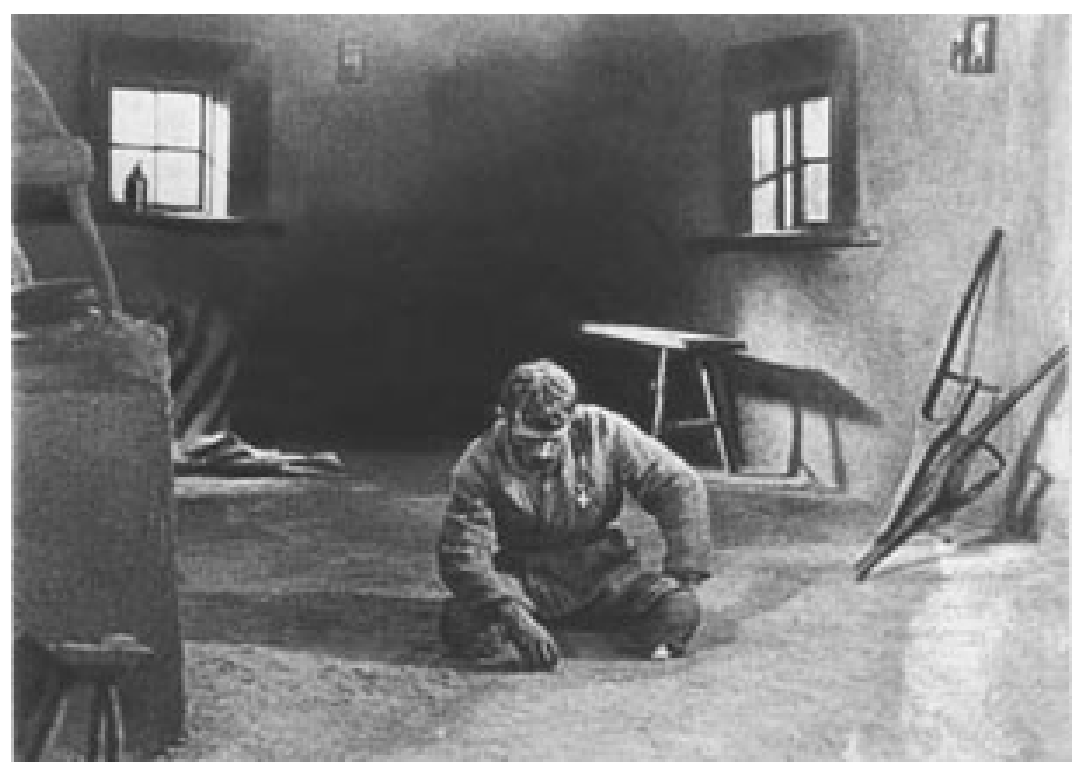

Figure 1: One of the opening scenes in Arsenal

resources from parents. Depending on differences in birth order, gender, physical traits, and aspects of temperament, siblings create differing roles for themselves within the family system. These differing roles in turn lead to disparate ways of currying parental favour. Eldest children, for example, are likely to seek parental favour by acting as surrogate parents toward their younger siblings. Younger siblings are not in a position to ingratiate themselves with parents in the same manner. Their niche is typically less parent identified, less driven by conscientious behavior, and more inclined toward sociability. As children become older and their unique interests and talents begin to emerge, siblings become increasingly diversified in their niches. ${ }^{(19)}$

According to Sulloway's study of scientific and political revolutionaries, "firstborns appear to be more similar in their personalities to other firstborns than they are to their own younger siblings." Eldest children tend to identify more closely with tradition, parents and authority. They are more extraverted, more assertive, and are more likely to possess leadership qualities than second-bourns. Firstborns tend to be more responsible and achievement-oriented than laterborns, who in turn are more socially successful than their older siblings. Laterborns are more easy-going, cooperative, and popular than firstborns. ${ }^{(20)}$ First bourns are not open to new experiences. Concerned about status, first bourns are more jealous, anxious, neurotic, and fearful than laterborns. ${ }^{(21)}$ Relative to their younger siblings, the eldest children are "also more conforming, conventional, and defensive" - characteristics which cut them off from new experiences. ${ }^{(22)}$

Sulloway claimed on the basis of his research that most innovations in science, especially radical ones, were initiated and championed by laterborns, not firstborns. The eldest children tended to reject new ideas, especially when the innovation appeared to upset long-accepted principles. ${ }^{(23)}$ Laterborns, according to Sulloway, were especially open to new experiences. But why? Openness, according to the author, helps younger siblings in their quest to find an unoccupied family niche. ${ }^{(24)}$ A child's family rank determines his or her openness.

Birth order, according to Sulloway, can be assessed as a biological as well as a functional category. In many cases, biological and functional birth order are the same. But due to sibling mortality, adoption, remarriage, and other circumstances, functional birth order does change. ${ }^{(25)}$

Sulloway's analysis is persuasive, but Dovzhenko does not completely fit into Sulloway's paradigm. At the heart of the problem is the question of Dovzhenko's status and promotion in the family's birth order due to the deaths in his family. Did Petro Semenovych and Odarka Ermolaivna treat their son as the seventh-born? When Alexander became the oldest sibling in 1905 did he experience, however temporarily, a psychological 
dislocation over being thrust into adult responsibilities while still an eleven year-old child? Perhaps.

Dovzhenko exhibited characteristics of both laterborns and firstborns. Similar to other firstborns, he was extraverted, conscientious, and neurotic. He acted as a surrogate parent toward his younger brothers and sisters. At the same time, similar to other laterborns, he was agreeable, and open to new experiences, especially in the new field of filmmaking.

Although we cannot completely re-construct and analyze Dovzhenko's birth order experience, the deaths in his family and Dovzhenko's jump in his family's birth order influenced the course of his life. Becoming the oldest child marked his transformation from a dependent child to the most responsible one.

Feeling the need to compensate his parents for the loss of their children, Dovzhenko became a model child. Polina, his only surviving sister, recounted how Alexander responded enthusiastically whenever his parents, whom he considered the alpha and omega of his life, asked him to do something. ${ }^{(26)}$ He probably encouraged himself by telling himself to be strong for his parents. As a responsible child, he immersed himself in his schoolwork and reading, the most common childhood reaction to a death in the family. ${ }^{(27)}$

Following in the footsteps of his hardworking grandfather and father, Alexander took on responsibilities around the house. Because of his mother's constant physical and emotional illnesses, Alexander took over her role. He swept the floors, washed dishes and clothes, brought in water from the well and wood for the stove, made the beds, and even baked bread while watching over his little brothers and sisters. Alexander also served his father. He often helped him in the fields to plow, mow, and harvest. From his parents and grandparents he learned to work hard and to become a perfectionist, not only in performing physical labour but also in his intellectual labours. ${ }^{(28)}$

Attending school and learning to read and write opened new opportunities for him, especially in a region where the overwhelming majority of the men and women remained illiterate. In 1902 he began his studies at the primary school in Sosnytsia, which like most schools in the Russian Empire taught the Bible and Orthodox precepts, Church Slavonic, Russian, writing, arithmetic, and singing. ${ }^{(29)}$ Here Alexander learned to read. Soon he became one of the most active patrons of the town's library. He finished primary school in the spring of 1906 and by the fall began the first class of the town's three-class (later four-class) higher elementary school. ${ }^{(30)}$

Alexander Petrovych excelled at the two elementary schools, which he enjoyed attending. His love of learning did not end with the school day. When he came home from school, he immediately began to read and to prepare his homework. His mother admonished him to eat something, then study. But, according to his sister, he "never sat at the dinner table before finishing his lessons." ${ }^{(31)}$

Whether or not this account is true, school became Alexander's sanctuary from death. Here, his mastery of reading, writing, arithmetic, and theology -- not his family birth-order -- ranked him. Death rarely disturbed his schooling.

An intelligent and talented boy, he became self-disciplined and mastered his school subjects. Ivan Trofymovych Tyshyna, who sat next to Alexander Petrovych in class in 1904, remembered the ten-year old as "quiet, sensible, well-mannered and fastidious." His clothes and boots always appeared clean and his books were never soiled. Alexander became the best pupil in class; arithmetic became his best subject. Whenever a classmate would give the wrong answer, the math teacher would call on Alexander. His teachers loved him, and long after he left the Sosnytsia elementary schools, they cited him as "the good student" all pupils should emulate. ${ }^{(32)}$

After he graduated from the higher elementary school in the spring of 1911, Alexander had to think about his future. During his elementary school years he aspired to be a wanderer, a sailor, an artist, an architect, and a writer, but he never expressed any thoughts about becoming a teacher. ${ }^{(33)}$ In his 1939 autobiography he claimed that he decided to become a teacher because he was successful in school. ${ }^{(34)}$ In reality, Dovzhenko became a teacher in large part because he enjoyed the school environment, a haven from death. As a teacher, he could critically analyze the past and present, nurture his students, and control his environment.

In the fall of 1911 Alexander took the entrance examinations to the Teacher's Institute in Hlukhiv, which he successfully passed. In the fall of 1914 Dovzhenko became a teacher of science and physical education at 
the Second Mixed Higher Elementary School in Zhytomyr, where he taught until 1917.

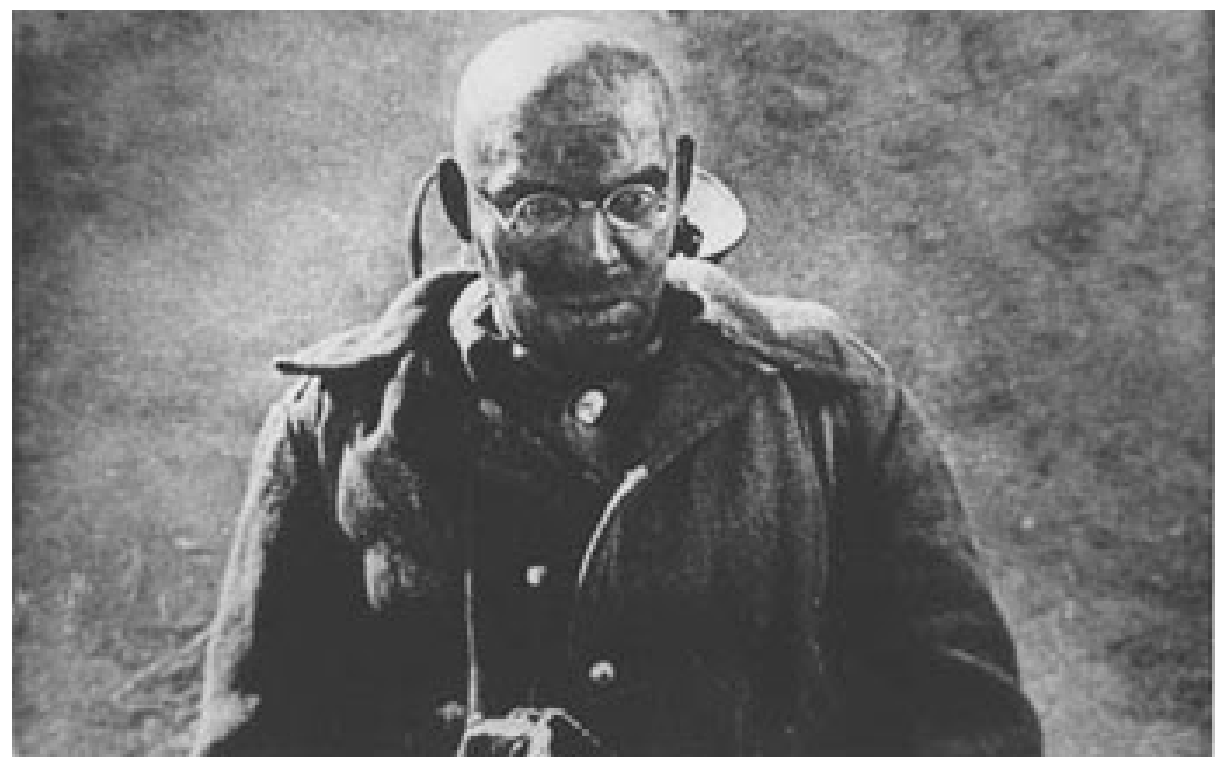

Figure 2: Gassed German soldier (Amvrosii Buchma) in Arsenal

As a result of his schooling and the education he received at home, Alexander Dovzhenko became a member of the intelligentsia, an educated man with a political conscience and with a commitment to political action. Most of all, he felt a sense of social responsibility, which parallelled his family duties. From an early age, he -- a middle child -- took on the obligations of caring for his brothers and sisters. As an intelligent, he felt responsible for making life better for the poor and for the oppressed. He wanted to make a difference by becoming a teacher.

Dovzhenko held the teaching profession in high regard throughout his life. He asserted that the profession "was a very necessary, responsible, and an honourable one." He advised a friend who became a teacher: "You should love your work and profession and give yourself completely to it. Only then will it be possible to see the results of your work and be happy." (35) Praising another friend from Hlukhiv who became an educator, he wrote that "you are the greatest cultural presence in the village. You can do much for your native country by teaching children." (36) It was unclear as to what Alexander meant by the phrase "native country" (the Russian Empire as a whole, or just the Ukrainian provinces?). However he defined the term, teaching in his eyes remained an important responsibility.

Teaching became the vocation which would allow him to do the greatest good for the most people. He would teach children, become their mentor and introduce them to new ideas. Dovzhenko would not only teach subjects such as physics, mathematics, and art, but he would impress on his pupils that hard work, self-improvement, and critical thinking could lead to positive social changes. By becoming a teacher he would confront social, political, and national oppression. He would struggle in a subtle and quiet manner, but these were his most effective weapons. He could do more to subvert the tsarist reality as a teacher than as a member of any other profession.

Becoming a teacher meant not only responsibility, but respectability as well. Dovzhenko's search for respectability mirrored his search for approval. Young Alexander eagerly strove to please his parents and teachers, hoping to gain approval from figures of authority. He was very polite, obedient, and self-effacing. His external behavior elicited positive reactions from adults, who approved of and encouraged his behavior. They must have viewed him as an adult in a child's body, which he became with the deaths in his family and his increasing family responsibilities. Although at times he rebelled against authority, he did not do it in public, but behind the scenes. He never presented himself as a rebel. Alexander always sought the approval of his friends and of those in charge. Approval brought respectability and acceptance. 
But the search for respectability did not necessarily encourage Dovzhenko's responsibility to promote social justice and the Ukrainian identity, however he defined it. For Dovzhenko, the search for respectability and the search for responsibility often came into conflict.

Dovzhenko always remained a teacher, attempting to balance responsibility and respectability, even after he left the teaching profession. His filmmaking became a war against ignorance by other means.

All men and women are haunted by death, by their own mortality. As a result of the deaths in his family, Dovzhenko - one of the middle children -- became the oldest child. Occupying this position he expected to die before his younger brothers and sisters. Despite these unspoken assumptions, all but one of his younger siblings died before him. Death violated the natural order of life. The deaths in his family and Dovzhenko's jump in his family's birth order exacerbated his anxiety regarding death.

Psychologists claim that adult survivors of childhood sibling loss are more worried about death than any of the other groups. "Leaving loved ones behind when you die" and "dying before accomplishing everything you wanted to do" constituted the most commonly reported fears of death. But surviving siblings, as did Dovzhenko, admitted more anxiety about these commonly expressed concerns. ${ }^{(37)}$

Although Dovzhenko mentioned the deaths in his family, he never publicly described their emotional consequences on him or acknowledged his own fear of death. He fled from it. He wrote:

Now, whenever I think of my childhood and of my home, I see in my mind crying and funerals. And the first telegram that came to our house told us of the death of my brother, who had been working as a stevedore in Rostov. I still cannot bear to look at funerals, and yet they pass through all of my scripts and all my pictures.In all my films there is parting. My heroes say good-bye as they rush off somewhere far away, on to a different life, unknown but alluring. To keep their hearts from breaking they say good-bye hastily and carelessly without looking back. It's the ones who stay behind who cry. ${ }^{(38)}$

Instead of staying behind, Dovzhenko attempted to repress his memories of death by fleeing. He said good-bye to his family, left the peasant life, and rushed off to a different life (becoming a student, teacher, revolutionary, Soviet bureaucrat, diplomat, illustrator, filmmaker, and writer) in the towns and cities (Zhytomyr, Kiev, Kharkiv, Warsaw, Berlin, Odessa, and Moscow) far away from Sosnytsia. He sought to break with the emotional and physical ties to his past, to move beyond the reach of death.

Burying painful memories of the past may camouflage a person's anxiety concerning death, but painful memories do not totally disappear from one's consciousness. Repressing painful memories, moreover, may fertilize new ideas. According to Ernest Becker, "repression is not simply a negative force opposing life energies. It lives on life energies and uses them creatively." (39)

As a result of the deaths of Dovzhenko's siblings and his promotion in the family's birth order, these emotional disasters enhanced his creative powers. His reactions to the sad events in his youth -- his contemplation, imagination, dreams, and fantasies -- prepared him to enter the world of filmmaking, the best medium for expressing his teaching and story-telling abilities. Film could translate Dovzhenko's private dreams into public illusions. Although these illusions did not necessarily coincide with reality, they presented another reality.

In addition to the fear of leaving loved ones behind when he died, Dovzhenko feared dying before accomplishing everything he wanted to accomplish. Only in 1926, when Dovzhenko turned thirty-two, did he enthusiastically embrace his new vocation as a film director. His creativity as a filmmaker and his hard-work ethic represented his reactions to death. He felt that he had much to offer the world in terms of his creativity, but by the early 1930s he came to fear arrest, the end of his creativity and the end of his life. This is why he publicly came to support the Stalinist order, why he sought "the security that is promised by tying into a system that will meet our dependency needs and help us deny our intrinsic vulnerability."(40)

Dovzhenko did not like to speak of death and rarely wroteabout it. But he did say:

Edison was right: the most valuable treasure in the world is time. I know by my own experience and I often want to cry when I remember how much time I lost and often not on that which I was fated (to master). ${ }^{(41)}$ 


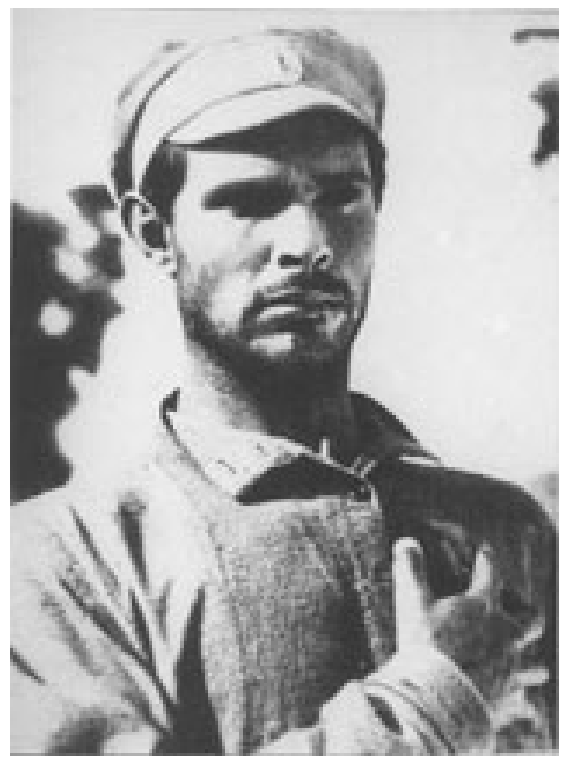

Figure 3: Tymish (Semen Svashchenko) in Arsenal

He possessed an artistic temperament; he was restless. He wanted to create as many excellent films as he could. Having become a filmmaker late in life, he must have felt that time was not on his side.

The majority of the deaths Dovzhenko encountered in his family and in his environment conformed to his definition of "senseless" deaths. In order to compensate for these deaths, he presented the deaths of his cinematic heroes as meaningful deaths. Arsenal (1928), for example, opens with dramatic scenes of victims of the Great War. In one scene, a Ukrainian veteran, a double amputee, sits on the floor of his house, totally useless to his family (Figure 1). In another scene, a German soldier experiences a gas attack, then spasms of laughter as he dies (Figure 2). These deaths are senseless and illogical. The first man is healthy, but physically useless; the second masks pain and imminent death with his laughter.

In contrast, the main hero, Tymish (a Ukrainian Bolshevik), experiences a meaningful death (Fig. 3). In the film's concluding scenes he makes a courageous last stand at the Arsenal in Kiev against the troops under the command of the Ukrainian nationalist Central Rada. When his machine gun jams, the Rada's troops overrun his position. Tymish rips his shirt open and defies his enemies to shoot him. They do, but their bullets fail to harm him. Then, in an extraordinary conclusion, the Rada's soldiers literally disappear in the face of his defiance.

Here, Dovzhenko presented an allegorical death experience which defied the laws of physics and of biology. Tymish's invulnerability stemmed from his revolutionary idealism, which will never be extinguished. ${ }^{(42)}$ One's revolutionary idealism will triumph, even if one dies. As in the Christian belief, life will triumph over death.

In Earth (1930), both the grandfather (Semen) and his grandson (Vasyl) die: the grandfather by natural causes, the grandson as a result of murder. The opening scene suggests that the old man, having lived a full life, now faces death at peace with himself. Before Semen died, he eats a fresh apple (Figure 4). He then lays down and passes away. According to the film critic Vance Kepley, Jr., the apples that lay on the ground, like the old man, are associated with death. These apples will never be eaten; they will decompose and enter back into the soil, replenish the ground, and thus serve as a source of renewal. This opening scene emphasizes the themes of life, death, and regeneration which run throughout the film. ${ }^{(43)}$

Vasyl's death also include these themes. During Vasyl's funeral procession, the branches and leaves of the trees gently brush against his face, as if they were reaching out to touch him one last time before his burial (Figure 5). ${ }^{(4)}$ In the final scenes young members of the farm collective sing the "Song of the New Life." Dovzhenko contrasts Vasyl's funeral with several references to fertility: the young people of the procession 


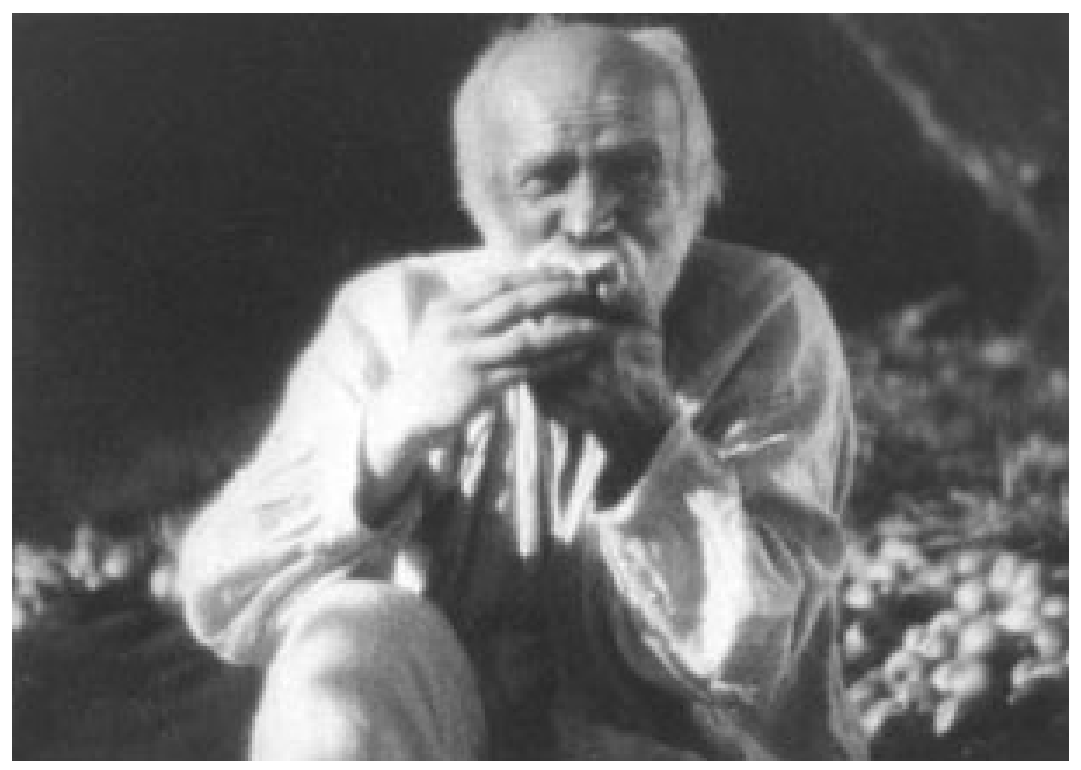

Figure 4: The grandfather's (Mykola Nademsky) death scene (Earth)

carry bouquets and branches, and as the funeral is underway, Vasyl's mother goes through labour and gives birth. Death, as Dovzhenko suggested, is an integral part of life. Life, death, and rebirth constitute nature's dialectic. ${ }^{(45)}$

In Shchors (1939), Dovzhenko portrays Ukrainian Bolshevik resistance to the 1918 German intervention and to Symon Petliura's Ukrainian nationalist forces during the Civil War. Young Mykola Shchors leads the Bohun Brigade and the salty old peasant Vasyl Bozhenko heads the Taranshchansk Regiment (Figure 6). Both join forces under Shchors's command.

In the film, Dovzhenko presents Bozhenko's death and burial. As Bozhenko is laid to rest in the field of battle, Shchors asserts: "We will remember you in twenty years." (46) Bozhenko died, but his friends promise to honour his memory in the future. In death, Bozhenko achieves a communist immortality.

Although Shchors actually died in 1919, two weeks after Bozhenko died, Shchors lived beyond 1919 in Dovzhenko's film. Why? Why did Dovzhenko create an ending which omitted Shchors' death?

In order to survive, Dovzhenko had to bow to Stalinist orthodoxy. The 1938 arrest of Dovzhenko's old friend Ivan Dubovy, who had served under Shchors and who was a consultant on the film, stunned the director. Before his execution, Dubovy's interrogators forced him to sign an incredible confession, in which Dubovy professed to have assassinated Shchors "to take his place as commander of the division." (47) One can only imagine Dovzhenko's political vulnerability. The NKVD arrested his own military consultant in the middle of production and "unmasked" him as the murderer of the film's title character. Dovzhenko clearly did not want to incorporate this new interpretation of Shchors's death into his film. The only way to deal with Shchors' death was to deny it. ${ }^{(48)}$ Dovzhenko's cinematic Shchors then lived longer than the actual Shchors.

Concerned with death, Dovzhenko presented different interpretations of death in his films. Reacting to the many tragedies in his own past, the filmmaker sought to grapple with death, to make sense of it, and to present it in a better light. Although his treatment of death in his films differed from the "senseless" deaths he encountered in real life, a psychological umbilical cord connected them. Dovzhenko rewrote the deaths from his past and placed them within a political context. He made his cinematic deaths more meaningful and more optimistic than the ones in his own life. His presentations of death emphasized that revolutionary idealism would triumph over death, that life, death, and regeneration were intimately connected, and that death can bring immortality. Most importantly, as Dovzhenko demonstrated in dealing with Shchors, he could also deny death on the screen. As a filmmaker, Dovzhenko was skillful enough to edit both life and death. 


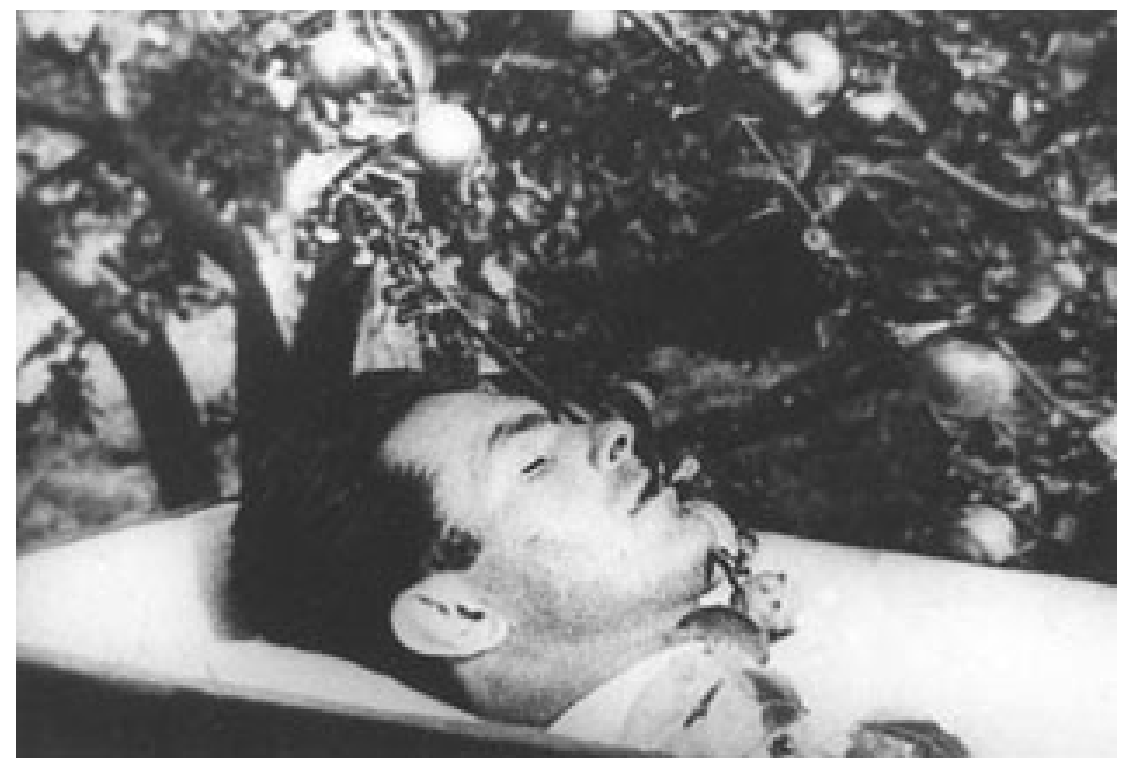

Figure 5: Vasyl's (Semen Svashchenko) funeral procession (Shchors)

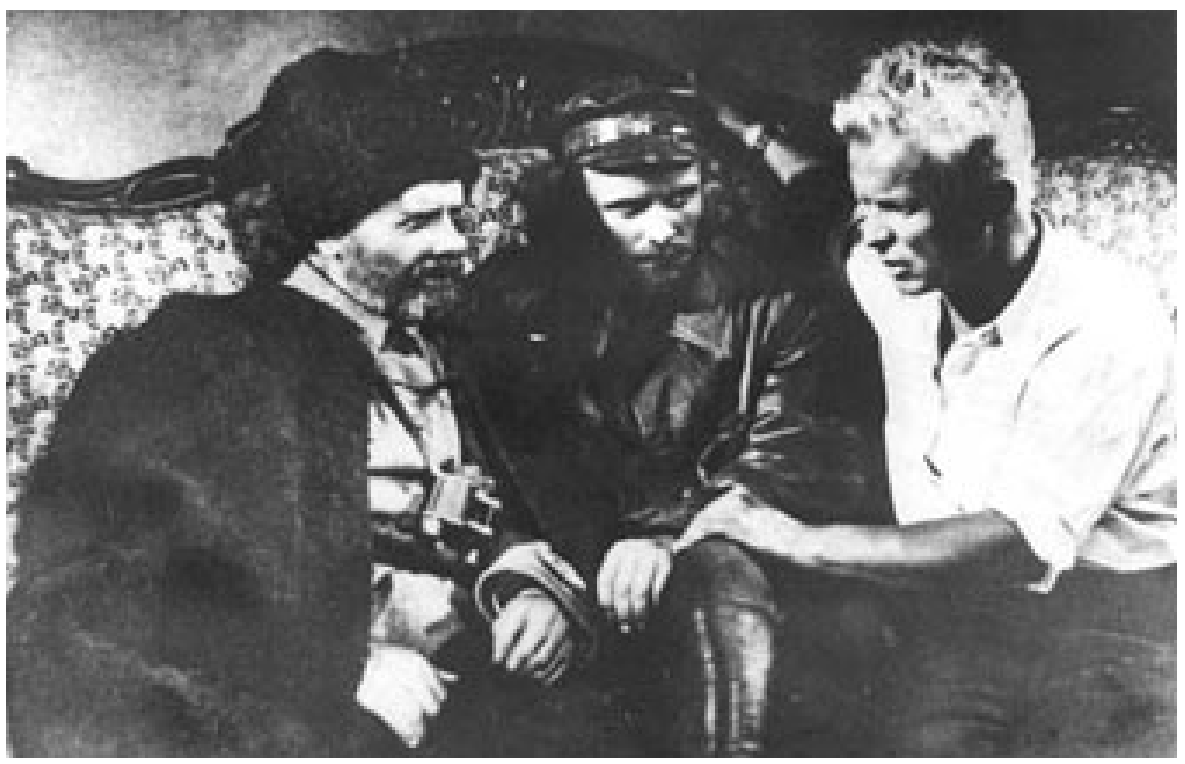

Figure 6: Dovzhenko (r.) with I. Skuratov and E. Samoilov on the set of Shchors. 


\section{Notes}

1. Amanhal Bartelemi, "Svit novoi liudyny," in S.P. Plachynda, ed., Dovzhenko i svit (Kiev, 1984), p. 126.

2. Ibid.

3. Heorhii Stoianov-Bihor, "Velykyi mytets, polumianyi propahandyst," in S.P. Plachynda, ed., Dovzhenko $i$ svit, p. 184.

4. Until 1949 Dovzhenko claimed to have been born on August 30/September 12, 1894. It is unclear why Dovzhenko asserted this. Drawing on baptismal records, Dovzhenko's biographer Mykola Kutsenko wrote that he was born 29 August 1894 and baptized on 30 August. M.V. Kutsenko, Storinky zhytia $i$ tvorchnosti O.P. Dovzhenka (Kiev, 1975), p. 7. August 29, 1894 (Old Style) equals September 10, 1894 (New Style). See Professor I.S. Astapovich's "Spravka" from March 25, 1970, Auxiliary Materials, Sosnytsia Dovzhenko Museum.

5. Iakiv Nazarenko, in his "Dorohy dytynstva ta iunosti," in Iulia Solntseva and Leonid Novychenko, eds., Polum'iane zhytia: Spohady pro Oleksandra Dovzhenka (Kiev, 1973), p. 128 (cited hereafter as POZ), asserted that Alexander was the seventh child in his family. In Nazarenko's "Ego shkol'nye gody," Raduga, no. 9 (1964), p. 141, he claimed that Alexander was the ninth child. Whatever the case, Dovzhenko was one of the middle children.

6. Vitalii Pryhorovs'kyi, "Tarasovychka: Do 100-richchia vid dnia narodzhennia O.P. Dovzhenko," Desnians'ka pravda, July 19, 1994, p. 3.

7. P.P. Dovzhenko-Dudko, "Pro brata," POZ, p. 115.

8. Hanna Pylypivna Senchenko, Russian State Archive of Literature and Art (Moscow), f. 2081, op. 1, d. 1212, p. 39. From now on, I will identify this archive by its Russian acronym, RGALI.

9. P.P. Dovzhenko-Dudko, "Pro brata," POZ, p. 115.

10. Quoted in Vitalii Pryhorovs'kyi, "Tarasovychka," p. 3.

11. N.V. Kolenko, RGALI, f. 2081, op. 1, d. 1212, and Museum of the Dovzhenko Film Studios (Kiev), Dovzhenko Museum Memoirs, File 1. Cited hereafter as DMM.

12. Marco Carynnyk, "Alexander Dovzhenko's 1939 Autobiography," Journal of Ukrainian Studies, XIX, no. 1 (Summer 1994), p. 10. Cited hereafter as "1939 Autobiography".

13. Alexander Dovzhenko, The Poet as Filmmaker: Selected Writings. Edited by Marco Carynnyk (Cambridge, MA, 1973), p. 94.

14. S. Turchyk, "Dushevnoi krasy liudyna," Za radianskyi film, 28 January 1958. S. Turchyk's unpublished memoirs, "Nash Sashko," identifies Dovzhenko's companion as Maksym Chereshnevyi. "Nash Sashko," RGALI, f. 2081, op. 1, d. 1196, pp. 3-8, provides more details than Turchyk's published account.

15. "1939 Autobiography", p. 8.

16. Helen Rosen, Unspoken Grief: Coping with Childhood Sibling Loss (Lexington, MA and Toronto, 1986), p. 15 .

17. "1939 Autobiography," p. 9.

18. Colin Murray Parkes, "Bereavement as a Psychosocial Tran-sition: Processes of Adaptation to Change," in Margaret Stroebe, Wolfgang Stroebe, and Robert O. Hansson, eds., Handbook of Bereavement: Theory, Research (Cambridge, Eng., and New York, 1993), p. 92.

19. Frank Sulloway, Born to Rebel: Birth Order, Family Dynamics, and Creative Lives (New York, 1996), p. 21.

20. Sulloway, pp. 55, 68-73. 21. Sulloway, pp. 68-73. 22. Sulloway, pp. 21-22. 23. Sulloway, p. 53. 24. Sulloway, p. 86. 25. Sulloway, p. 22. 
26. P.P. Dovzhenko-Dudko, "Moi vospominaniia," RGALI, f. 2081, op. 1, d. 1124, p. 12.

27. Rosen, p. 33.

28. I. I. Lytavchyk, RGALI, f. 2081, op. 1, d. 1212, p. 24.

29. Ben Eklof, Russian Peasant Schools: Officialdom, Village Culture, and Popular Pedagogy, 1861-1914 (Berkeley, CA and London, 1986), pp. 483-487.

30. Lytavchyk, p. 24. 31. Dovzhenko-Dudko, p. 12.

32. I. T. Tyshyna, RGALI, f. 2081, op. 1, d. 1212, p. 46.

33. Ia. Nazarenko, "Dorohy dytynstva i iunosti," p. 137. 34. "1939 Autobiography," p. 9. 35. "Spohady Marii Tymofiivny Nyrkovskoi," Sosnytsia Dovzhenko Museum, File A-228.

36. I. A. Koval, "Moi vospominaniia ob A.P. Dovzhenko," DMM, File 1, p. 2 (This passage does not appear in I. Koval, "Sered maibutnikh pedahohiv," POZ, p. 138).

37. Rosen, p. 70. 38. "1939 Autobiography," pp. 7-8.

39. Ernest Becker, The Denial of Death (New York and London, 1973), p. 21.

40. Robert Kastenbaum, The Psychology of Death, 2nd ed. (New York, 1992).

41. RGALI, f. 2081 , op. 1, d. 1194, p. 22.

42. Vance Kepley, Jr., In the Service of the State: The Cinema of Alexander Dovzhenko (Madison, WI, 1986), p. 72.

43. Kepley, p. 79. 44. Kepley, p. 81. 45. Kepley, p. 82. 46. Kepley, p. 131.

47. N.S. Khrushchev, Khrushchev Remembers, with an introduction, commentary, and notes by Edward Crankshaw (Boston, 1970), p. 88.

48. Kepley, p. 132.

\section{Author Information}

George O. LIBER is Associate Professor of History at the University of Alabama at Birmingham. He is the author of Soviet Nationality Policy, Urban Growth, and Identity Change in the Ukrainian SSR, 1923-1934; he recently completed Triple Exposure: Alexander Dovzhenko's Ukrainian Visions, Soviet Illusions, and Stalinist Realities. 